\title{
Thank You to Reviewers
}

Journal of International Business Studies (2007) 38, 2 I I. doi: I0. I057/palgrave.jibs.8400256
Correction to: Journal of International Business Studies (2007) 37, 932-935. doi: 10.1057/palgrave.jibs.8400237

In the above list of reviewers, Joseph A Clougherty was incorrectly listed as John Clougherty. We apologise to Professor Clougherty, and thank him for his valuable work reviewing manuscripts for JIBS during this period. 